\title{
PRELIMINARY DATA ON THE MINERALOGY OF LIMESTONE AND SKARN-HOSTED CAVES FROM BĂ IȚA (BIHOR COUNTY, ROMANIA)
}

\author{
BOGDAN P. ONAC ${ }^{1} \&$ PAUL DAMM ${ }^{2}$
}

\begin{abstract}
This paper presents the mineralization of five medium-size limestone-caves and eleven skarn-hosted caves from the upper part of Crișul Bă itei River (Bihor Mountains). Apart from berlinite - $\mathrm{AIPO}_{4}$, the other minerals reported from the limestone caves are common carbonates, phosphates or oxyhydroxides. In turn, the skarn-hosted caves contain a diversity of minerals, including wittichenite, luzonite, natrolite, norsethite, rosasite, glaukosphaerite, aurichalcite, azurite, malachite and chalcanthite. Five of these minerals have never before been identified in a cave environment and moreover, three are new occurrences in Romania. Some of these minerals are hydrothermal in origin, whereas alteration and/or hydration of primary hydrothermal minerals formed the others. Considering the mineral assemblage, the morphology and the position of cavities within the skarn bodies, we assume these minerals formed during one of the following stages: hydrothermal, hydrothermal/vadose or vadose.
\end{abstract}

Keywords: karst, skarn, hydrothermal, mineralogy, speleogenesis, Bă ița Bihor, Romania.

\section{INTRODUCTION}

The mineralogy of limestone caves is straightforward, as the main mineral species found are calcite, aragonite and gypsum. In addition, the presence of bat guano deposits is responsible for the precipitation of various phosphate minerals. However, caves located adjacent to metamorphic or volcanic terrains or those hosted within skarn bodies, volcanic tuffs, sandstones or evaporite rocks may show a complex and diverse mineralogy. It is this situation of the skarn-hosted cavities we are presenting in this paper. The objectives of the present study are to present the preliminary results on the mineralogy of caves from Bă ita-Bihor region and to assess what processes led to the deposition of the identified minerals.

To accomplish our goal we collected twenty-six samples representing crusts, corraloids, crystals and various type of aggregates from seven limestoneand eight skarn-hosted caves, all located in the upper part of Crișul Bă iței River. Their mineralization was studied using a combination of optical microscopy

${ }^{1}$ Department of Mineralogy, "Babeș-Bolyai" University, Kogă Iniceanu 1 \& "Emil Racoviță "Institute of Speleology, Clinicilor 5, 3400 Cluj, Romania (bonac@bioge.ubbcluj.ro).

2 "Transilvania General Company", Teatrului 1-2, 3700 Oradea \& Speleological Club "Z”, 14/4, 3576 Astileu, Bihor, Romania. 
(Nikon Optiphot 2-POL), scanning electron microscopy (Stereoscan 250 MK3Cambridge equipped with energy-dispersive spectrometer), and stable isotope analysis (Finnigan MAT 251 mass spectrometer). Step-scan CuK ${ }_{\alpha}\left(\lambda_{\alpha 1}=1.5405\right)$ X-ray powder diffraction data (XRD) were collected with a standard Philips PW1800 diffractometer fitted with a curved graphite diffracted-beam monochromator. The step-scan data were collected over the range $5-70^{\circ} 2 \theta$ using a step interval of $0.02^{\circ} 2 \theta$.

Minerals were characterized solely based on XRD data when the spectrum was complete and well resolved. When multiple minerals phases occurred in the sample, additional investigations were conducted.

\section{GEOGRAPHIC \& GEOLOGIC SETTING}

The investigated area lies in the south-western part of the Bihor Mountains, in the well-known metallogenetic district of Bă ița-Bihor (Fig. 1, inset). The landscape in the region has high relief and is heavily forested.

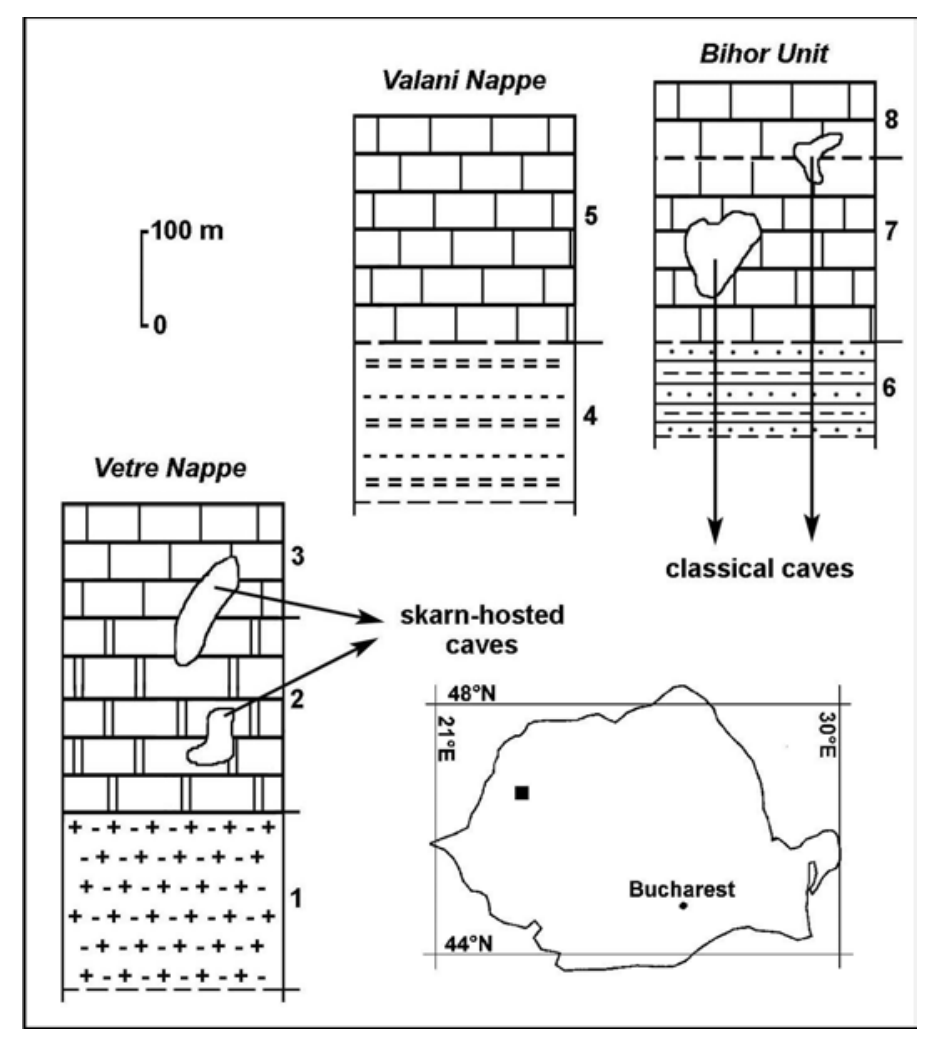

Fig. 1. Synthetic lithostratigraphic columns showing the formations that host caves and the location of Bă ița-Bihor karst region. 1: quartzites \& hornfelses (Triassic); 2: Fră sinel marble;

3: Bă ița marble; 4: Coșuri Beds; 5 \& 7: Upper Jurassic limestones; 6: Permo-Triassic formations; 8: Lower Cretaceous limestones. 
The bedrock geology consists of a complex tectonic setting bringing into contact several nappe systems belonging to the Bihor and Apusenides structural units (Balintoni, 2001). In the Bă ița-Bihor area, the lowermost unit of the Codru Nappe system is the Vetre Nappe, which shows a complete Triassic sequence. The formations of interest for our investigations consist of quartzites and hornfelses of Ladinian to Lower Carnian age, Fră sinel dolomite marble (Carnian), and Bă ița marble (Norian) (Bleahu et al., 1994). Within this area, outcrops of slightly or unmetamorphosed limestones of Upper Jurassic and Lower Cretaceous age occur. In several sectors of the upper Crișul Bă iței basin, the Triassic metamorphosed carbonate rocks (Vetre Nappe) are in tectonic contact with quartzites and hornfelses of Coșuri Beds (Vă lani Nappe) (Matyasi et al., 2001). The geological column is shown in Fig. 1.

The rich calcic and/or magnesian skarn bodies from this region host economic deposits of $\mathrm{Mo}, \mathrm{W}, \mathrm{Bi}, \mathrm{Cu}, \mathrm{Pb}$ etc. that have been mined since the Middle Ages. Their genesis is related to a deep-seated Laramian pluton of granitic to dioritic composition (Stoici, 1983). Several scientific reports and papers have been published on the geology of this important mining district of Romania (Stoicovici \& Stoici, 1972; Cioflica et al., 1974, 1995, Cioflica \& Vlad, 1979; Stoici, 1983 and Matyasi et al. 2001, among others). Stoici (1983) mentions a number of caves accidentally discovered during mining of the skarn ore deposit and comments on the genesis of these cavities and their mineralogy.

The only karst papers that describe this region are those by Posepny (1874), Vă lenaș et al. (1977), Oră șeanu (1997) and Damm (1998, 2000). None, however, contains information on cave mineralogy or speleogenesis of the skarn-hosted caves.

\section{SPELEOLOGICAL SETTING}

The most important category of caves we studied within the Bă ița-Bihor region are those formed within the skarn bodies. Thirteen cavities (for 4 of them we have data obtained from published or unpublished old geological reports) were investigated with respect to their mineralogy. With few exceptions the caves are poorly decorated and short (none of them exceeding $100 \mathrm{~m}$ ), but often show notable positive or negative relief. A striking feature is the way their galleries closely follow the metasomatic contact between Coșuri Beds and the mineralized skarn bodies.

The other category of caves includes those formed by classical solution processes. These eight caves are formed either in the Upper Jurassic or Lower Cretaceous, unmetamorphosed and metamorphosed limestone or at the boundary between these formations and the Cossuri Beds. The length of these caves may exceed $1,000 \mathrm{~m}$ and are well decorated. All known caves from this karst region are listed in Table 1. 


\section{RESULTS OF MINERALOGICAL ANALYSES}

Our analyses led to the identification of two sulfides (Iuzonite and wittichenite), two silicates (natrolite and quartz), two hydroxides (romanechite and goethite), six hydrous carbonates (aurichalcite, azurite, glaukosphaerite, hydromagnesite, malachite, and rosasite), three carbonates (calcite, aragonite, and norsethite), two phosphates (berlinite and hydroxylapatite), and one sulfate (chalcanthite). Out of these eighteen minerals, six are for the first time identified in caves worldwide and prior to our study three have never been reported in anz mineral occurrence from Romania.

Table 1.

List of limestone- and skarn-hosted caves of Bă ița-Bihor mining district (the caves we sampled are shown in italics).

\begin{tabular}{|c|c|c|}
\hline Cave name \pm hosting mining galleries & $\begin{array}{l}\text { Length \& relief } \\
\text { (m) }\end{array}$ & $\begin{array}{c}\text { Host } \\
\text { host rock }\end{array}$ \\
\hline The cave from Aloisie Mine & $56 /+16$ & \multirow{13}{*}{ skarn } \\
\hline Water Cave from Codreanu Mine & $65 / 26(-11,+15)$ & \\
\hline Crystal's Cave from Codreanu Mine & $44 / 20(-13,+7)$ & \\
\hline The cave from Elena Mine & $110 /+8$ & \\
\hline Water Cave from Karoli Mine & $32 /-14$ & \\
\hline The cave from lohann Mine & $47 /+3$ & \\
\hline The cave from Gustav Mine & $60 /-16$ & \\
\hline The cave from Franz Mine & unexplored & \\
\hline Small Cave from Bolfu III Mine & $93 /+3$ & \\
\hline Big Cave from Bolfu III Mine & $402 / 58(-25,+33)$ & \\
\hline Surprise Cave from Tony Mine & ca. 550 & \\
\hline The cave from Schachtadel shaft & unexplored & \\
\hline Izbuc Cave from Coșuri Valley & $80 /+5$ & \\
\hline Izvorul Crișului Negru & $1,155 /+45$ & \multirow{8}{*}{$\begin{array}{c}\text { limestone } \\
\text { dolomite } \\
\& \\
\text { marble }\end{array}$} \\
\hline Pereții Corlatului & $247 / 29(-18,+11)$ & \\
\hline Tunnel Cave from Corlatu Valley & $38 / 3(-1.5,+1.5)$ & \\
\hline Condorului & $110 /+8$ & \\
\hline Schmidl & $141 /+7$ & \\
\hline Mare & $75 /-8$ & \\
\hline The cave from Quarry & $500 /-60$ & \\
\hline Porțile Bihorului & $220 /-65$ & \\
\hline
\end{tabular}

\section{Sulfides}

The antimonian variety of luzonite $-\mathrm{Cu}_{3}\left(\mathrm{As}_{0.64} \mathrm{Sb}_{0.36}\right) \mathrm{S}_{4}$ - was identified by means of XRD when analyzing thin grayish-black crusts $(<4 \mathrm{~mm}$ in thickness) collected from the walls of Crystal's Cave (Codreanu Mine). In some parts newly formed calcite crusts or clusterites coat these dark crusts. The diffraction spectrum of luzonite is shown in Fig. 2. 
Wittichenite - $\mathrm{Cu}_{3} \mathrm{BiS}_{3}$ - form lead-grey granular aggregates in Big Cave from Bolfu III Mine. The strongest 14 XRD lines of this mineral are identical or closely match those reported by Nuffield (1947). The chemical composition obtained by AAS analysis (wt\%) gave $\mathrm{Cu} 37.54$, Bi 41.72, S 19.22 and $\mathrm{Pb} 1.14$.

Without any doubt the two minerals are of hydrothermal origin. They may have been deposited either within the carbonate host rock and displayed later when solution processes cut across the skarn or in pre-existing hydrothermal or meteoric karst channels. This problem is still open, but is clear that both luzonite and wittichenite under oxidizing conditions may have altered to various hydrous carbonates.

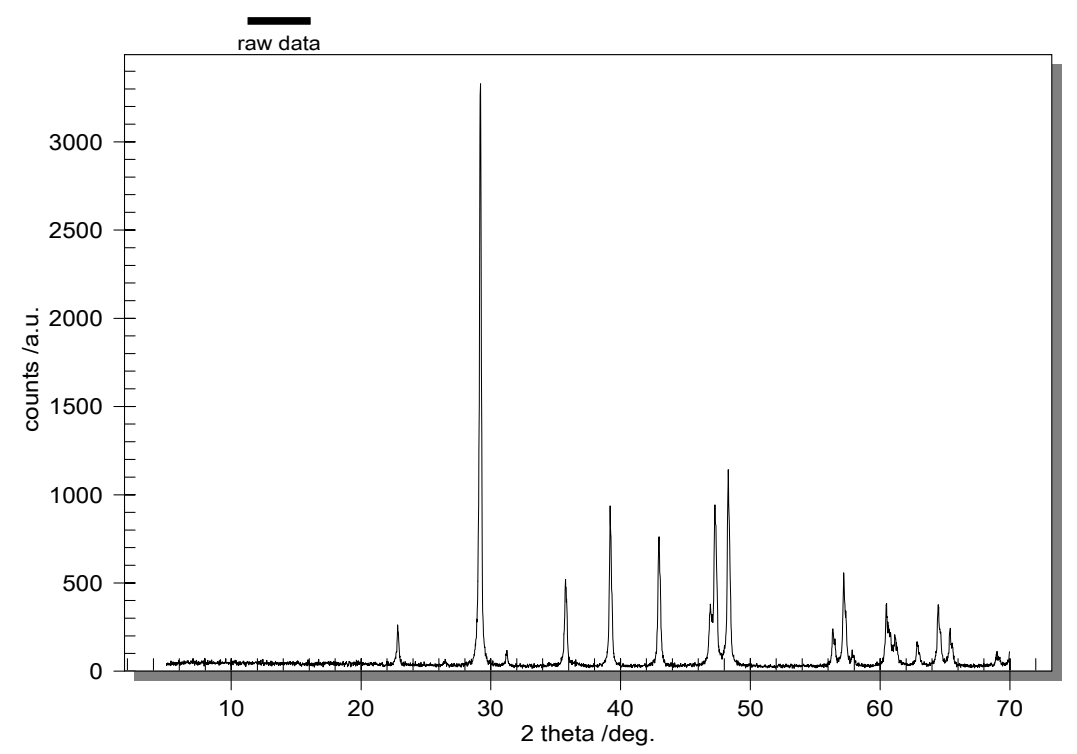

Fig. 2. The diffraction patterns of luzonite.

\section{Silicates}

Natrolite $-\mathrm{Na}_{2}\left[\mathrm{Al}_{2} \mathrm{Si}_{3} \mathrm{O}_{10}\right] \cdot 2 \mathrm{H}_{2} \mathrm{O}$ - was found in the Big Cave from Bolfu III Mine as millimeter size patches of granular crusts or fibrous aggregates associated with calcite. It appears as glassy and opaque-white. The identification relies solely on XRD analysis.

Fine quartz $-\mathrm{SiO}_{2}-$ crystals build up concentric layers intermixed with calcite crystals, being an indication of past hydrothermal conditions. This mineral has been identified in the clusterites that grow on the walls of Water Cave from Codreanu Mine. The clusterites never exceed $1 \mathrm{~cm}$ in length and appear either as colorless or shades of yellow-brown colors.

\section{Carbonates}

Calcite - is by far the most common and abundant mineral forming a large variety of speleothems. These include coatings, crusts, stalactites, stalagmites, columns, flowstones, moonmilk, helictites and spars. However, only Surprise 
Cave and the two cavities from Bolfu III Mine are well decorated with calcite speleothems. The cavities from Codreanu Mine were almost completely devoid of speleothems due to the ore mining. Depending on the quantity of inorganic or organic trace impurities, the color of calcite speleothems in these caves varies from pure white to dark brown, including yellow and orange shades.

Investigations carried out on some of the calcite speleothems (e.g., clusterites) suggest some are of hydrothermal origin. Isotopic analyses showed depleted ${ }^{18} \mathrm{O}$ values (i.e., between -10 and $-16.7 \%$ PDB) for the suspected hydrothermal calcite whereas the ${ }^{18} \mathrm{O}$ values are less negatives (i.e., -4 to 8.3\% PDB) in the low-temperature cave environment calcite speleothems.

Botryoidal corraloids made up of aragonite were found in the two caves from Bolfu III Mine. Aragonite was identified by means of XRD analyses and microscope observations.

Hydromagnesite $-\mathrm{Mg}_{5}\left(\mathrm{CO}_{3}\right)_{4}(\mathrm{OH})_{2} \cdot 4 \mathrm{H}_{2} \mathrm{O}$ - is the prime constituent of moonmilk and nodules found on the floor and walls of two cavities from Bolfu III Mine and Izvorul Crișului Negru Cave. The color of hydromagnesite speleothems is cream to chalk white. The diffraction patterns obtained on our samples are complete and well resolved, fitting exactly the reference patterns of hydromagnesite (corresponding to the trigonal system, space group R32).

Except for the three minerals presented above all the other carbonates were found only in the skarn-hosted caves.

Malachite $\mathrm{Cu}_{2}{ }^{2+}\left(\mathrm{CO}_{3}\right)(\mathrm{OH})_{2}$, azurite $\mathrm{Cu}_{3}{ }^{2+}\left(\mathrm{CO}_{3}\right)_{2}(\mathrm{OH})_{2}$ and aurichalcite $\left(\mathrm{Zn}, \mathrm{Cu}^{2+}\right)_{5}\left(\mathrm{CO}_{3}\right)_{2}(\mathrm{OH})_{6}$ - are widespread secondary minerals in the oxidation zones of copper-bearing ore deposits. These three mineral species (identified by means of XRD analyses) were found in cavities from Elena and Karoli mines. In all of these locations, bright green to olive-green malachite and intense blue lustrous azurite generally stains and coats the bedrock, the calcite crusts, and the pebbles along the stream. A fragile pale-green or light-blue crust of aurichalcite lines the sectors of the walls. In some parts of the cavities these minerals fill or line small fissures or corrosion pockets in the cave walls (PI. I, Figs. 1, 2). Both malachite and azurite were also identified by their optical properties.

In the Water Cave from Codreanu Mine, malachite is closely associated with rosasite - $\left(\mathrm{Cu}^{2+}, \mathrm{Zn}\right)_{2}\left(\mathrm{CO}_{3}\right)(\mathrm{OH})_{2}$ - and glaukosphaerite - $(\mathrm{Cu}, \mathrm{Ni})_{2}\left(\mathrm{CO}_{3}\right)(\mathrm{OH})_{2}$. Rosasite appears as bluish-green needles, 0.05 to $2 \mathrm{~mm}$ in length, forming efflorescences on bedrock and calcite crusts. Glaukosphaerite, a mineral of the rosasite group (Mandarino, 1999), typically occurs in this cave as thin coatings of deep green color. Although many authors cite glaukosphaerite appearing alongside rosasite, it has never been previously reported in an association from a cave environment.

The identification of the two minerals is based on X-ray diffraction and chemical analyses (Table 2). As seen in Table 3, the diffraction data of rosasite and glaukosphaerite differ significantly, hence, easily distinguishing them when appearing in the same sample. The unit cells of rosasite and glaukosphaerite closely correspond to those reported on their ICDD files. The small differences between the cell parameters obtained in this study and the reference are interpreted as a slight difference in their chemical composition. 
PRELIMINARY DATA ON THE MINERALOGY OF LIMESTONE AND SKARN-HOSTED CAVES ...

Table 2

Average wet-chemical analyses (wt\%) for three samples of rosasite and glaukosphaerite.

\begin{tabular}{c|c|c|c}
\hline \multicolumn{2}{c|}{ Rosasite } & \multicolumn{2}{c}{ Glaukosphaerite } \\
\hline $\mathrm{CuO}$ & 42.21 & $\mathrm{CuO}$ & 41.87 \\
$\mathrm{ZnO}$ & 30.87 & $\mathrm{NiO}$ & 30.77 \\
$\mathrm{CO}_{2}$ & 19.82 & $\mathrm{CO}_{2}$ & 18.64 \\
$\mathrm{H}_{2} \mathrm{O}^{+}$ & 7.27 & $\mathrm{H}_{2} \mathrm{O}^{+}$ & 8.51 \\
Total & $\mathbf{1 0 0 . 1 7}$ & Total & $\mathbf{9 9 . 7 9}$ \\
\hline
\end{tabular}

Table 3

Comparison of X-ray powder diffraction data for rosasite and glaukosphaerite from Bă ița-Bihor.

\begin{tabular}{|c|c|c|c|}
\hline \multicolumn{2}{|c|}{ Rosasite } & \multicolumn{2}{|c|}{ Glaukosphaerite } \\
\hline $\mathrm{d}(\AA)$ & $\mathrm{I}$ & $\mathrm{d}(\AA)$ & 1 \\
\hline 7.4618 & 17 & 7.3998 & 20 \\
\hline 6.071 & 43 & 5.976 & 40 \\
\hline 5.118 & 94 & 4.713 & 11 \\
\hline 3.7425 & 100 & 3.702 & 70 \\
\hline 3.059 & 14 & 3.033 & 17 \\
\hline 2.892 & 73 & 2.978 & 80 \\
\hline 2.545 & 60 & 2.84 & 29 \\
\hline 2.478 & 29 & 2.781 & 25 \\
\hline 2.199 & 10 & 2.596 & 100 \\
\hline 2.146 & 18 & 2.521 & 54 \\
\hline 1.963 & 15 & 2.461 & 38 \\
\hline 1.911 & 10 & 2.318 & 13 \\
\hline 1.799 & 6 & 2.189 & 9 \\
\hline 1.685 & 13 & 2.129 & 20 \\
\hline 1.4823 & 14 & 1.999 & 7 \\
\hline & & 1.935 & 17 \\
\hline & & 1.676 & 11 \\
\hline & & 1.647 & 6 \\
\hline & & 1.587 & 13 \\
\hline & & 1.497 & 10 \\
\hline & & 1.474 & 8 \\
\hline & & 1.3006 & 5 \\
\hline & & 1.267 & 5 \\
\hline \multicolumn{2}{|c|}{$\begin{array}{l}a=9.3321 \pm 0.043 \AA \\
b=11.9905 \pm 0.081 \AA \\
c=3.1375 \pm 0.088 \AA \\
\beta=88.31 \pm 2.93^{\circ}\end{array}$} & \multicolumn{2}{|c|}{$\begin{array}{l}a=9.4395 \pm 0.023 \AA \\
b=11.9421 \pm 0.019 \AA \\
c=3.0524 \pm 0.014 \AA \\
\beta=90.52 \pm 0.5^{\circ}\end{array}$} \\
\hline
\end{tabular}

The last of the carbonates identified is norsethite $-\mathrm{BaMg}\left(\mathrm{CO}_{3}\right)_{2}-\mathrm{a}$ rare rhombohedral double carbonate. It appears as well crystallized white nodular aggregates on the walls of Crystal's and Surprise caves. The X-ray reflections seem to be closer to those of dolomite. However, the essential 
difference between the two species is that the reflections of norsethite, located between 46 and $49^{\circ} 2 \theta$, are shifted about $2.5^{\circ} 2 \theta$ from the dolomite spectrum where they appear from 48.5 to $51.5^{\circ} 2 \theta$. Moreover, norsethite posses three distinct lines at $21.02,33.52$, and $41.84^{\circ} 2 \theta$ respectively, which are missing on the calcite spectrum.

Least-squares refinement using the diffraction data yields the following R32 rhombohedral cell parameters for Bă ița-Bihor norsethite: $a=5.0494 \pm 0.0487 \AA$; $c=16.9928 \pm 0.2251 \AA$. Further investigations are to be conducted to understand the way this mineral was precipitated in the cave environment.

\section{Phosphates}

Hydroxylapatite - $\mathrm{Ca}_{5}\left(\mathrm{PO}_{4}\right)_{3}(\mathrm{OH})$ - appears in Peretii Corlatului and Izvorul Crișului Negru caves as millimeter-thick, fragile brown to black crusts. It precipitates only in areas were bat colonies are to be found. Hydroxylapatite was identified by means of XRD.

The other phosphate mineral, berlinite $-\mathrm{AlPO}_{4}$ - was found in a remote passage in Peretii Corlatului Cave forming small crusts made up of tiny gray crystals. The location where the sample was collected is situated in the vicinity of the geological contact between limestone and the metamorphosed rocks of Coșuri Beds. Knowing that berlinite typically forms at temperatures above $186^{\circ} \mathrm{C}$ (Bass \& Sclar, 1979) we believe it has a hydrothermal origin. The X-ray diffraction data for the sample are as follow $d(\AA) / I: 4.269 / 22 ; 3.981 / 2 ; 3.648 / 2$; $3.367 / 100 ; 2.472 / 9 ; 2.305 / 10 ; 2.253 / 5 ; 2.131 / 6 ; 1.987 / 7 ; 1.681 / 4 ; 1.552 / 7$; $1.461 / 2 ; 1.388 / 5,1.301 / 2 ; 1.235 / 2 ; 1.195 / 2$. Presently, we cannot discriminate whether it is a true cave mineral or not. Berlinite was recently reported for the first time in a cave environment from Cioclovina Cave (Onac et al., 2002).

\section{Sulfates}

Blue, millimeter size crystals of chalcanthite have been found in the close vicinity of the secondary copper carbonates in the Water Cave from Codreanu Mine. The XRD patterns of our sample are sharp and overlap almost all reflections recorded in the ICDD card no. 11-646 of chalcanthite (Fig. 3). In this occurrence, the copper comes from chalcopyrite, whereas sulfate is supplied by strongly acidic water (from pyrite oxidation).

\section{Hydroxides}

Either goethite $-\alpha-\mathrm{Fe}^{3+} \mathrm{O}(\mathrm{OH})$ or romanechite $-\left(\mathrm{Ba}, \mathrm{H}_{2} \mathrm{O}\right)\left(\mathrm{Mn}^{4+}, \mathrm{Mn}^{3+}\right)_{5} \mathrm{O}_{10}$ have been found in most of the investigated caves (except for Condorului and Schmidl) as orange, red-brown and black coatings on alluvial clasts and cave walls close to the water level. The XRD spectra were poorly resolved; therefore, our identification was based on IR and chemical analysis. The presence of goethite in these caves is attributed to oxidation of Fe-rich minerals, while romanechite may have been directly precipitated in oxidizing environments from underground streams or seeping waters. 


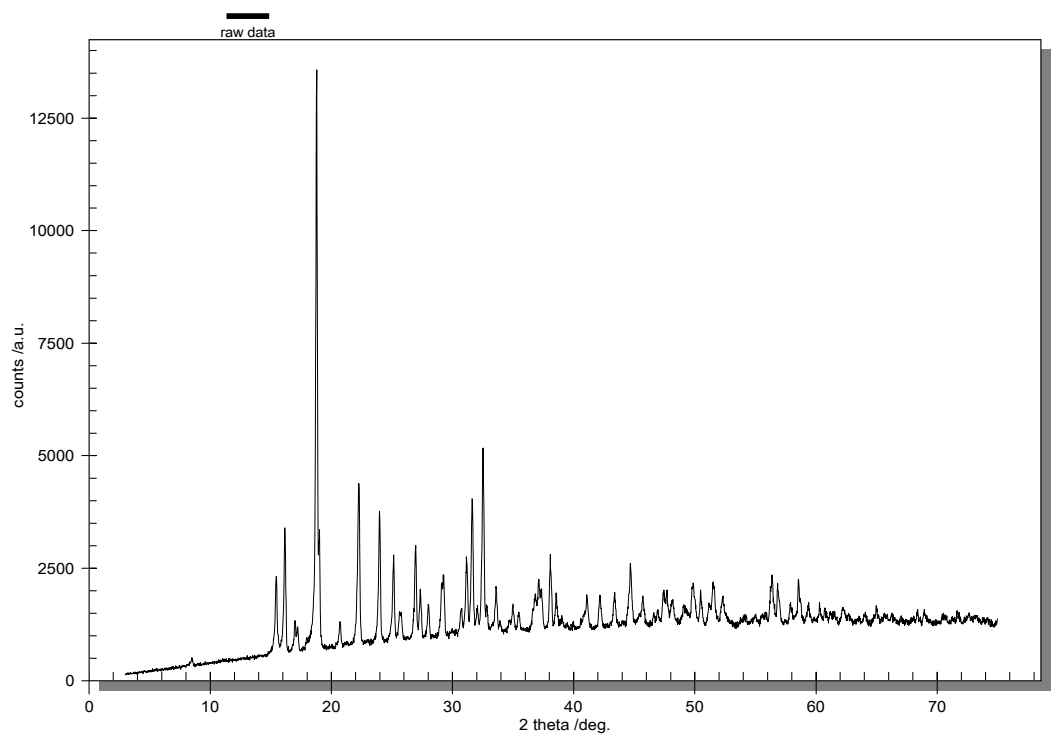

Fig. 3. The diffraction patterns of chalcanthite.

\section{CONCLUSIONS}

The minerals presented in this paper were assigned to the following three genetic categories:

(1) minerals deposited from hydrothermal solutions (wittichenite, luzonite, berlinite, quartz, and partly calcite);

(2) minerals that are hydration or alteration products of primarily hydrothermal deposited minerals (natrolite, goethite, malachite, aurichalcite, rosasite, glaukosphaerite, chalcanthite etc.);

(3) minerals precipitated from low-temperature vadose solutions (calcite, aragonite, hydromagnesite, hydroxylapatite, goethite etc.).

The question we have to answer is which of the above-mentioned minerals are true secondary minerals formed in caves? (see Hill \& Forti, 1997 for details). If all those included in the third category fulfill the condition requested for a cave mineral, some of the others listed in the first group are questionable. Quartz and calcite speleothems of hydrothermal origin are well documented from many caves around the world. Moreover, various sulfides were often found associated with quartz crystals in cavities hosted by skarn bodies (Dublyansky, 1997). Even so, we are still searching for more evidence before including luzonite and wittichenite into the cave minerals group. As already mentioned, except for the particular occurrence from Cioclovina Cave, berlinite was only documented from hydrothermal mineral assemblages. The minerals grouped in the second genetic category are in our opinion likely to be all true cave minerals. 
Although still preliminary, this paper reports and partly characterizes 18 minerals assigned to 6 chemical classes. Three of them, rosasite, glaukosphaerite, and norsethite are not included in Udubașa's (1999) checklist of valid mineral species known in Romania. Furthermore, five of the mineral species (true or not cave minerals), luzonite, wittichenite, natrolite, glaukosphaerite and norsethite are new for the cave environment worldwide.

Acknowledgements. Permission for sampling the caves was granted by "Emil Racoviță" Institute of Speleology. Minvest Deva Company gave permission to enter the old mining galleries. We thank the members of the Speleo Club "Z" and the following persons for assistance in the field: M. Petrescu, M. Zotescu, N. Feier, T. Brad, and S. Matyasi for useful discussions on the local geology. J. Kearns is thanked for proof reading. We acknowledge the support of the European Community Access to Research Infrastructure action of the Improving Human Potential Programme, contract HPRI-CT-1999-00008 awarded to Prof. B. J. Wood (EU Geochemical Facility, University of Bristol) that enabled us to perform part of the XRD and electron-microprobe analysis.

\section{REFERENCES}

BALINTONI, I.C. 2001, Short outlook on the structure of the Apuseni Mountains. In $4^{\text {th }}$ Regional Meeting of IFAA, Field trip guide (I.I. Bucur, S. Filipescu \& E. Să să ran, eds.), Cluj, Romania, pp. 9-17.

BASS, J. D. \& SCLAR, C. B. 1979 , The stability of trolleite and the $\mathrm{Al}_{2} \mathrm{O}_{3}-\mathrm{AlPO}_{4}-\mathrm{H}_{2} \mathrm{O}$ phase diagram. American Mineralogist 64, pp. 1175-1183.

BLEAHU, M., MANTEA, G., BORDEA, S., PANIN, S., STEFĂNESCU, M., SIRIC, K., HAAS, J., KOVACS, S., PERO, C., MAKK-BERCZI, A., KONRAD, G., NAGY, E., FELGENHAUER-RALISCH, E. \& TOROK, A. 1994, Triassic facies types, evolution and paleogeographic relations of the Tiszia Megaunit. Acta Geologica Hungarica 37 , pp. 187-234.

CIOFLICA, G. \& VLAD, S. 1979, Bi-sulfosalts related to Laramian skarns of the Bihor Mountains (Northern Apuseni Mountains). Revue Roumain Géologie, Géophysique et Géographie, Géologie 23, pp. 15-21.

CIOFLICA, G., VLAD, S., IOSOF, D. \& PANICAN, A. 1974, Thermal and metasomatic metamorphism of the Paleozoic rocks belonging to the Arieseni Unit (Baita Bihorului). Studii și Cercetă ri de Geofizică , Geografie, Geologie 19, pp. 43-68.

CIOFLICA, G., JUDE, R., LUPULESCU, M. \& SIMON, G. 1995, New data on the Biminerals from the mineralizations related to Paleocene magmatites in Romania. Romanian Journal of Mineralogy 76, pp. 9-23.

DAMM, P. E. 1998, La relation karst - parakarst dans la génèse de la grotte de Pereții Corlatului (Monts du Bihor, Roumanie). Travaux de l'Institute de Spéologie "Emil Racovitza"XXXVII.

DAMM, P.E. 2000, Peștera de la Izvorul Crișului Negru. Speomond 5, pp. 27-28. 
PRELIMINARY DATA ON THE MINERALOGY OF LIMESTONE AND SKARN-HOSTED CAVES ...

DUBLIANSKY, Y.V. 1997, Hydrothermal cave minerals. In Cave Minerals of the world (C.A. Hill \& P. Forti, eds., $2^{\text {nd }}$ ed.), NSS, Huntsville, Alabama, pp. 252-255.

HILL, C.A. \& FORTI, P. 1997, Cave Minerals of the world. $2^{\text {nd }}$ ed., NSS., Huntsville, Alabama.

MANDARINO, J.A. 1999, Fleischer's Glossary of Mineral Species 1999. The Mineralogical Record, Inc., Tucson, Arizona.

MATYASI, S., MATYASI, L. \& VLAS, G. 2001, Studiul mineralogic și structural al mineralizatiilor polimetalice la nivelul orizontului XVIII Zona Antoniu și orizontul XVI zonele Baia Roșie și Terezia din cadrul Ză că mântului Bă ița Bihor în vederea stabilirii potențialului economic. Arhiva S. M. Baița \& GeoProspect Ltd., Ștei.

NUFFIELD, E.W. 1947, Studies of mineral sulpho-salts: XI-Wittichenite (Klaprothite). Economic Geology 42, pp. 147-160.

ONAC, B.P., BREBAN, R., KEARNS, J. \& TĂMAȘ, T. 2002, Unusual minerals related to phosphate deposits in Cioclovina Cave, Sureanu Mts. (Romania) Theoretical and Applied Karstology 15, pp. 27-34.

ORĂȘEANU I. 1997, Contributions to the hydrogeology of karst areas of the BihorVlă deasa Mountains (Romania). Theoretical and Applied Karstology, 9, pp. 185-214.

POSEPNY F. 1874, Geologisch-montanishe Studie der Erzlagerstattenlehre von Rézbánya, Budapest.

STOICI, S. 1983, The Baita Bihor metallogenic district. Academiei RSR, București (In Romanian with extended Engl. abstr.).

STOICOVICI, E. \& STOICI, S. 1972, Contributions to the investigation of the boron ores from superior area of the Black Cris (Baita, Bihor). Studia Univ. Babes-Bolyai, Geologia-Mineralogia, fasc. 1, pp. 3-10.

UDUBAȘA, G. 1999, Advances in mineralogy of Romania. Romanian Journal of Mineralogy 79, pp. 3-30.

VĂLENAȘ, L., BLEAHU, M., BRIJAN, P. \& HALASI, G. 1977, Inventarul speologic al Munților Bihor, Nymphaea, 5, pp. 209-335.

\section{Plate I.}

Fig. 1. Fissures lined by fibrous crystals of malachite (Water Cave from Codreanu Mine, crossed nicols, x10).

Fig. 2. Azurite crystal (Water Cave from Codreanu Mine, plane-polarized light, x40). 


\section{Plate I.}

Fig. 1

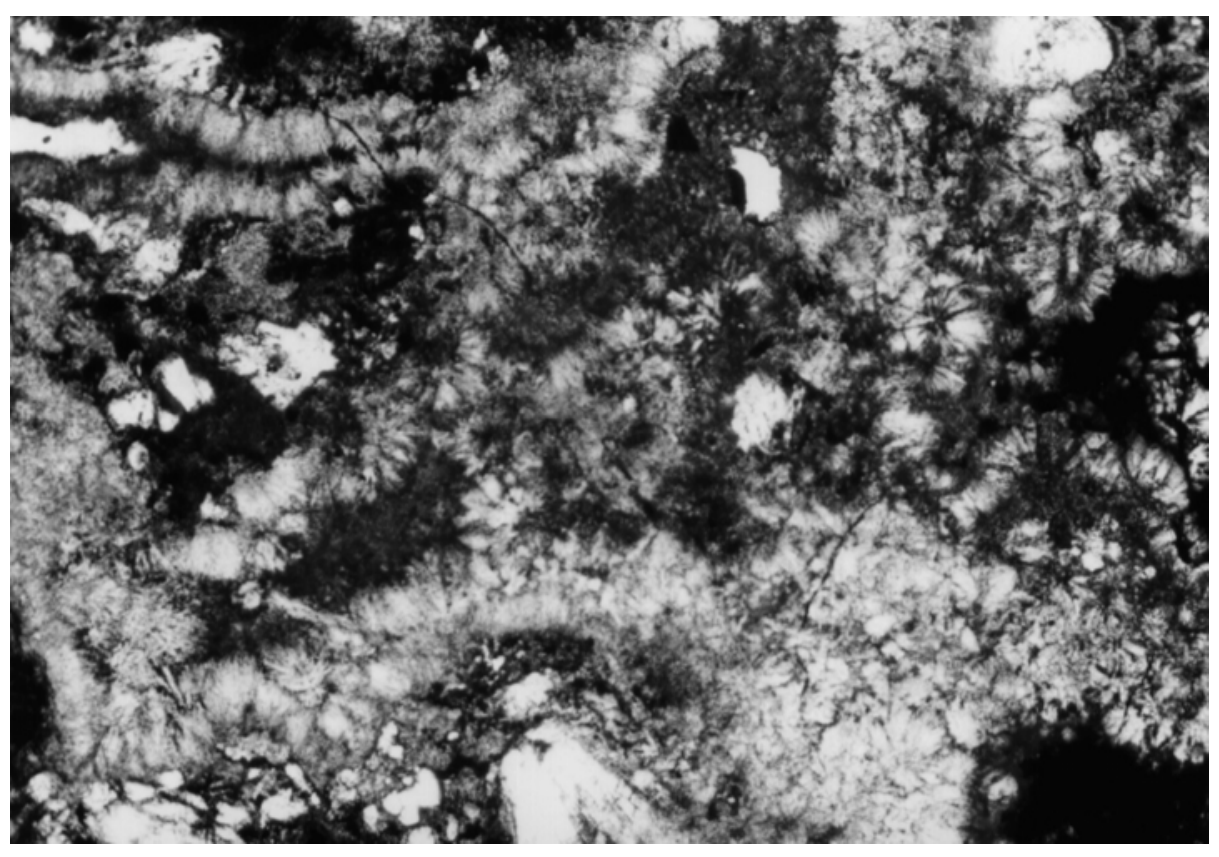

Fig. 2

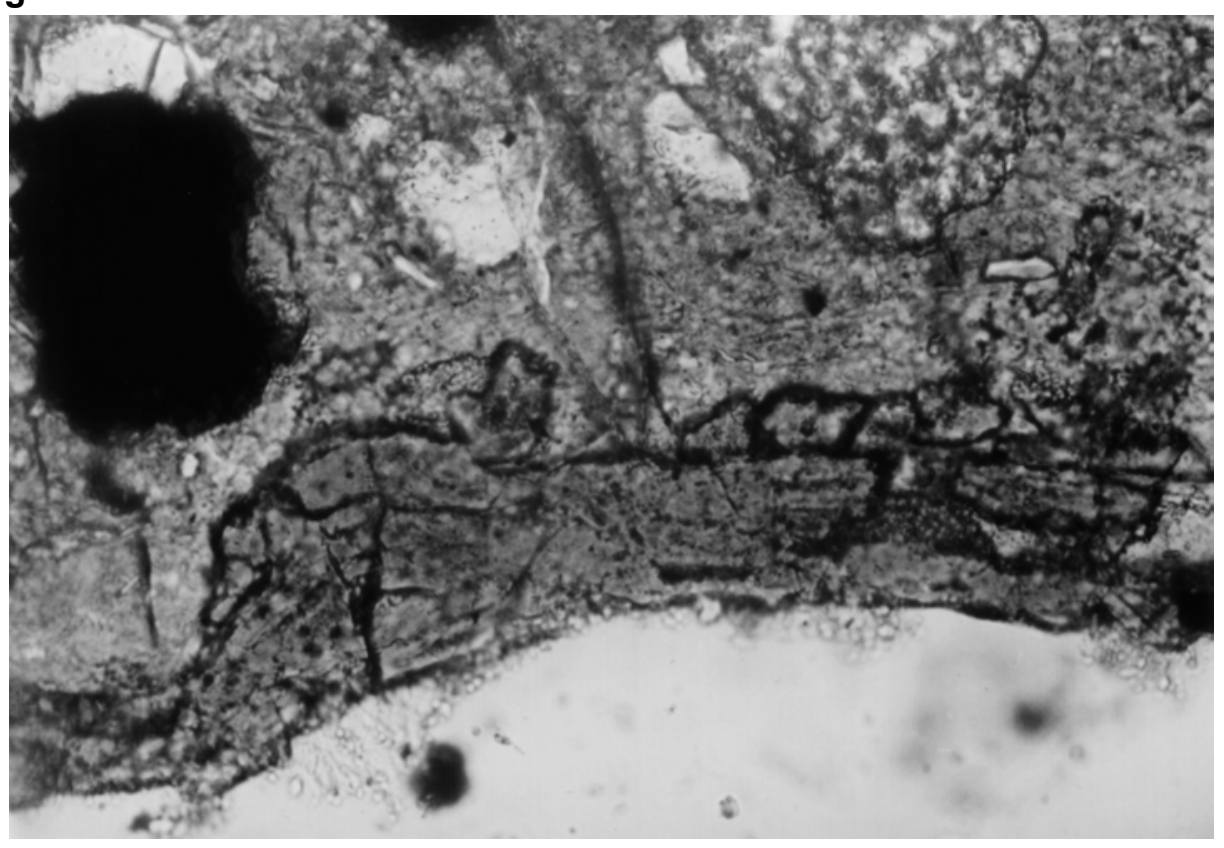

